responsible throughout. Later, it was urged that everything that is taught at all in a school should come round pretty nearly every day for at least one year. In the third stage of teaching, when hotany is studied for some special purpose, the great problems of the nutrition and reproduction of higher green plants should be specially studied. Such a course of plant physiology should occupy several hours a week for two or three years.

Miss von Wyss described how object lessons in botany might with advantage be given. She deprecated the idea that botany could be satisfactorily taught to young children apart from the study of zoology, and urged that such object lessons should be co-ordinated with the teaching of drawing and literature. The current idea that there is a difficulty in obtaining specimens in a large town was shown by the experiences Miss von Wyss related to be quite erroneous, and the success which object lessons have met with at the North London Collegiate School for Girls was dwelt upon.

\section{JUVENILE RESEARCH}

The afternoon meeting at the Imperial Institute was presided over by Sir Henry Roscoe. Prof. H. E. Armstrong, F.R.S., described in an interesting address the methods he had employed with his own children at home to educate them in the way of discovering for themselves the answer to questions which were presented in their ordinary life. The address was illustrated by practical demonstrations by Prof. Armstrong's little daughter and two young sons, and a series of lantern slides made it quite clear how the system described had been developed. In reading a book by the late Henry Drummond, called "The Monkey that would not Kill," the children cam e across the statement that a stone was lighter in sea-water than in air, and to satisfy themselves of the truth of the statement was the object of the piece of research which the children entered upon under the general supervision of their father. The steps in the inquiry were worked through again before a large audience, and the children themselves explained with remarkable intelligence what the object and result of each experiment were. Throughout the course of training, which was exemplified by the demonstration, each child kept a careful account of everything which was done, illustrating each step by means of sketches and recording every numerical result obtained. Prof. Armstrong maintained that the teaching of science to children was not commenced early enough, and that too little faith is shown by teachers in the reasoning faculties of young children.

\section{OBJECT LESSONS.}

The second day's meetings were held at the Shoreditch Technical Institute. Prof. Woods Hutchinson was to have given an address in the morning on "The Early Teaching of Natural History in Schools," but he was too ill to attend. Mr. I. W. Tutt read a paper on "Object Lessons in Natural History," in which he detailed the educational advantages of this method of instruction, the mode of giving a good object lesson, and a suitable scheme of lessons for young children. A discussion, in which a large number of teachers took part followed. But, from one cause and another, the subject in hand received very little attention, and few actual working methods were explained.

\section{MANUAI. WORK IN METAL.}

The concluding meeting was presided over by Sir J. F. D. Donnelly, and was concerned with the discussion of "Metal Work as a Form of Manual Instruction in Schools." Papers were read by Prof. W. Ripper, of University College, Sheffield, and Mr. Bevis, Director of Manual Instruction for the Birmingham School Board. Prof. Ripper's paper was concerned with the general considerations which make a development of the subject of manual instruction in metal desirable. It was pointed out that there has been a decided advance in this direction in recent years, and it was stated by Prof. Ripper that the exhibition of metal work in the Education Exhibition at the Imperial Institute is better than that of the recent Chicago Exhibition. Mr. Bevis gave an account of the course of instruction in metal work which was given to boys of Standards V. and VI., who were between the ages of ten and thirteen years, in the schools of the Birmingham School Board.

NO. I 577 , VOL. $6 \mathrm{I}]$

\section{UNIVERSITY AND EDUCATIONAL INTELLIGENCE.}

Cambringe.-Mr. A. H. Evans, M.A., of Clare College, who is favourably known as one of the authors of the " $\mathrm{C} \mathrm{zm}$. bridge Natural History," was, on January IO, elected an Esquire Bedell in succession to the late Mr. Gill.

The Special Board for Biology propose that legal powers shall be obtained to vary the conditions of the Gedge Bequest for the furtherance of physiological research, so as to equalise the conditions : on which "advanced students" compete with ordinary students for the prize under this foundation.

IN his dedication of the fourth volume of "The Linacre Reports" to the Vice-Chancellor of Oxford University, Prof. R. Lankester avails himself of the opportunity to make some remarks upon the want of encouragement given by Oxford Colleges to work of the kind contained in the volume. The position of science at Oxford has already been dealt with in detail in these columns (vol. liv. 1896). The present method of apportioning the College endowments is most unsatisfactory, and Prof. Lankester's suggestion that two-thirds of such endowments should be given for the encouragement of the study of the natural sciences, and one-third for the subjects comprised under the general terms Literæ Humaniores and Modern History, is a more reasonable distribution. In any case, Oxford is not likely to become a University for students of science while a past professor is justified in making a statement such as the following concerning the distribution of endowments :"It is, I know, useless to urge this, which is the judgment and practice of almost every University excepting our own, upon the consideration of those who now have the control of that splendid potential source of energy, the College endowments. They have, unfortunately, with rare exceptions, been brought up in complete ignorance of the scope and significance of the studies which they refuse to recognise; they deliberately and conscientiously use the advantage of their position so as to maintain the present one-sided system, and to discourage the study of the natural sciences by those who come as students to Oxford."

IT is not only at Oxford that study and research in the domain of the natural sciences receive little encouragement. In the preface to the volume of "Studies in Biology from the Biological Departments of the Owens College," Profs. S. J. Hickson and F. E. Weiss refer to the fact that no more Bishop Berkeley Research fellowships will be available for original work. The remark "Biology is now left in our College without any fellowship or scholarship to enable a promising student to devote a year of his life to original investigation before commencing his career as a teacher or medical student, and our well-equipped research laboratory has consequently to remain unoccupied during the greater part of the year. We cannot help feeling that if these facts were more generally known some help might be forthcoming from those who realise what biology has done and is doing for the development of rational methods of modern medical research." Why the Bishop Berkeley fellowships, which once promised to rank among the best characteristics of Owens College institutions, are not now available is not explained.

AT a general meeting of Convocation of London University held on Monday, the report of the standing committee was presented. The report dealt with the election by Convocation of members of the Senate under the new statutes. It stated that the representatives allotted to Convocation will have to be chosen in May. The representatives of Convocation will con sist of the Chancellor (elected for life), the chairman of Convocation, and sixteen members, of whom eight will retire every two years. These eighteen will form a najority of the members of the Council for external students, who will have to advise the Senate regarding the whole of the present work of the University. The Academic Council, elected mostly by teachers of the University, will perform a like function for internal students. There is no restriction on the choice of candidates. The new constitution will probably be in the hands of the University before the next meeting of Convocation in May, and by that time the University will probably have taken up its abode in its new home at the Imperial Institute. After a short discussion, the report was adopted. 